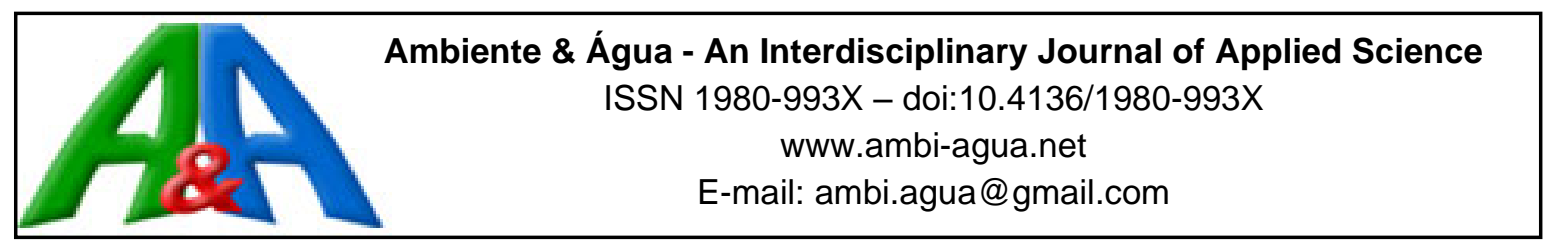

\title{
Hydropower plant in Eastern Amazon and its impacts on the local population's eating habits
}

\author{
ARTICLES doi:10.4136/ambi-agua.2700
}

Received: 27 Jan. 2021; Accepted: 19 Jul. 2021

\section{Wellinson Maximin de Souza Severino ${ }^{1}{ }^{\mathbb{D}}$; Erick Silva dos $\operatorname{Santos}^{1}{ }^{1 D}$; Helenilza Ferreira Albuquerque-Cunha ${ }^{2 *}$}

\footnotetext{
${ }^{1}$ Secretaria de Estado do Meio Ambiente do Amapá (SEMA/AP), Avenida Mendonça Furtado, ${ }^{\circ}$ 53, CEP: 68900-060, Macapá, AP, Brazil. E-mail: analista.wellinson@gmail.com, ericks_santos@hotmail.com ${ }^{2}$ Departamento de Meio Ambiente e Desenvolvimento. Universidade Federal do Amapá (UNIFAP), Rodovia Juscelino Kubitschek, Km 2, CEP: 68903-419, Macapá, AP, Brazil.

*Corresponding author. E-mail: helenilzacunha@gmail.com
}

\begin{abstract}
This study assessed the direct impacts of Cachoeira Caldeirão Hydropower Plant (before and during its construction) on the eating habits (fish and wild meat consumption) of the residents in Porto Grande City, Amapá State, Brazil. The study was conducted in 2015, based on a questionnaire for data collection (Sample size $=53$ ) and on comparative analysis for significance (Wilcoxon test, $p<0.05$ ) and correlation (Pearson's test) assessment. Results suggested significant changes in families' eating habits. The Wilcoxon test detected three significant variables $(p<0.05)$ : family income, number of species (fish and wild meat consumption) and rate of wild meat consumption per family. Both the Wilcoxon and the Pearson's correlation tests confirmed two variables $(p<0.05$ and $\mathrm{r}>0.7)$ : family income versus wild meat consumption before $(p$ value $=0.045 ; \mathrm{r}=-0.75)$ and family income versus fish consumption during ( $p$ value $=0.0029 ; \mathrm{r}=-0.83$ ) hydropower plant construction. It can be inferred that the decrease in family fish consumption may be related to changes in the families' eating habits. Changes in diet may have led families to a growing consumption of industrialized and/or ultra-processed foods, very common in geographically isolated Amazon riverside regions with limited access to electricity. Furthermore, families were forced to adapt to a new reality due to environmental changes in their territories.
\end{abstract}

Keywords: fish, socio-environmental impacts, wildlife species.

\section{Usina hidrelétrica na Amazônia Oriental e seus impactos nos hábitos alimentares da população local}

\section{RESUMO}

O presente estudo avaliou os impactos diretos da Usina Hidrelétrica Cachoeira Caldeirão (antes e durante sua construção) sobre os hábitos alimentares (consumo de peixes e carnes silvestres) de residentes na cidade de Porto Grande, Estado do Amapá, Brasil. O estudo foi realizado em 2015, com base na aplicação de questionário para coleta de dados (tamanho da amostra $=53$ ) e na análise comparativa para significância (teste de Wilcoxon, p <0,05) e avaliação de correlação (teste de Pearson). Os resultados sugeriram mudanças significativas nos hábitos alimentares das famílias. O teste de Wilcoxon detectou três variáveis significativas ( $\mathrm{p}$ 
$<0,05)$ : renda familiar, número de espécies (consumo de peixes e carnes silvestres) e taxa de consumo de carnes silvestres por família. Os testes de correlação de Wilcoxon e Pearson confirmaram duas variáveis ( $\mathrm{p}<0,05$ er $>0,7)$ : renda familiar versus consumo de carne selvagem antes (valor $\mathrm{p}=0,045 ; \mathrm{r}=-0,75$ ) e renda familiar versus consumo de peixe durante (valor $\mathrm{p}=0,0029 ; \mathrm{r}=-0,83$ ) construção de usina hidrelétrica. Pode-se inferir que a queda no consumo familiar de peixe pode estar relacionada à mudança de hábito alimentar das famílias. As mudanças na dieta alimentar podem ter levado as famílias ao consumo crescente de alimentos industrializados e/ou ultraprocessados, muito comuns em regiões ribeirinhas amazônicas isoladas geograficamente e com dificuldades de acesso a energia elétrica. Além disso, as famílias foram obrigadas a se adaptar a uma nova realidade devido às mudanças ambientais em seus territórios.

Palavras-chave: espécies silvestres, impactos socioambientais, peixes.

\section{INTRODUCTION}

Economic growth planning in developing countries is usually based on major infrastructure projects, which highly worsens environmental impacts at the local scale. Economic growth and policies in Brazil have been based on large businesses - such as hydropower plants throughout the last fifty years (Guimarães, 2003; Moretto et al., 2012).

This infrastructure-project type leads to the following main impacts: downstream and upstream activity impairments, water quality decrease, water body silting, waterborne disease increase, natural resource loss around reservoir areas and, mainly, local population and economic activities' compulsory displacement from affected areas (Acselrad, 2004; Giusti, 2005; Bermann, 2007; Araújo and Belo, 2009; Santos et al., 2017).

Therefore, building hydropower plants is one of the most controversial activities affecting development rates in tropical countries, as well as the leading cause of environmental and social issues. For example, the 79 planned Amazon dams are likely to flood approximately $3 \%$ of the forest and cause irreversible damage to local biodiversity and to traditional local populations (Zhouri and Oliveira, 2007; Sieben and Cleps Junior, 2012; Fearnside, 2013). Amazonian river basins have been overexploited in order to meet energy demands, and this accelerates the socioenvironmental degradation process and disregards appropriate environmental management (Filizola et al., 2002; Holanda et al., 2011).

Although hydropower plants are acknowledged for their advanced environmental protection policy, they remain controversial due to their impacts, namely: physical effects, socio-environmental changes in territories where they are installed and insufficient corrective and/or mitigation measures (Richter et al., 2010; Cavalcante and Santos, 2012).

The Araguari River is the most economically exploited basin for power generation in the Amapá State. Nowadays, it has three hydro power plants: Coaracy Nunes (UHECN), Ferreira Gomes (UHEFG) and Cachoeira Caldeirão (CCHPP) (Oliveira et al., 2010; Silva et al., 2016; Moreno et al., 2018).

Accordingly, hydropower plants have been the leading cause of significant socioenvironmental impacts on the Araguari River. The local population has been the most affected segment during the building and installation processes (Sousa, 2000; Sá-Oliveira et al., 2016; Santos et al., 2017).

The local population is mainly affected by negative effects on aquatic and terrestrial fauna dynamics - mainly on the riversides - due to hydropower plants, since they are socioeconomically, nutritionally and environmentally dependent on rivers (Begossi, 2004; Marques et al., 2018). Diagnoses on food sources and the social vulnerability of these populations can indicate the degree of dependence on, and the level of relationship with, local 
natural resources (Begossi, 1993; Zagallo and Ertzogue, 2018).

The relationship between populations and enterprises is asymmetrical, as popular access to the environment depends on other social strata. Thus, conflicts arise when natural resources from biodiverse systems are appropriated (Martinez- Alier, 1999; Acselrad, 2004).

Accordingly, the eating habits of local Amazonian residents are essential to assess natural resource sustainability and to measure the potential impacts of hydropower plants' construction, installation and operation (Lekwot et al., 2016; Zagallo and Ertzogue, 2018).

The present study assessed the factors affected by the construction of Cachoeira Caldeirão Hydropower Plant, as follows: family income in Porto Grande City (Amapá State, Brazil) residents, number of consumed fish and wildlife species, food consumption rate.

\section{MATERIALS AND METHODS}

\subsection{Study site}

Cachoeira Caldeirão Hydropower Plant (CCHPP) is located in Porto Grande City, Southern Amapá State, Brazil. Porto Grande City is $130 \mathrm{~km}$ away from Macapá (the capital city). It has a territorial area of $4.428 .013 \mathrm{~km}^{2}$, estimated population of 21.484 inhabitants and demographic density of 3.82 inhabitants $/ \mathrm{km}^{2}$ (IBGE, 2018).

Porto Grande City is bathed by the Araguari River, whose extensive water network is approximately $617 \mathrm{~km}$ in length and records $0.955 / \mathrm{km}$ drainage rate (Cunha et al., 2011). According to the new Brazilian river basin classification by the National Water Agency (ANA), the Araguari River Basin is entirely located within the Amazon Basin region, most precisely within Amapá State’s hinterlands (Figure 1).

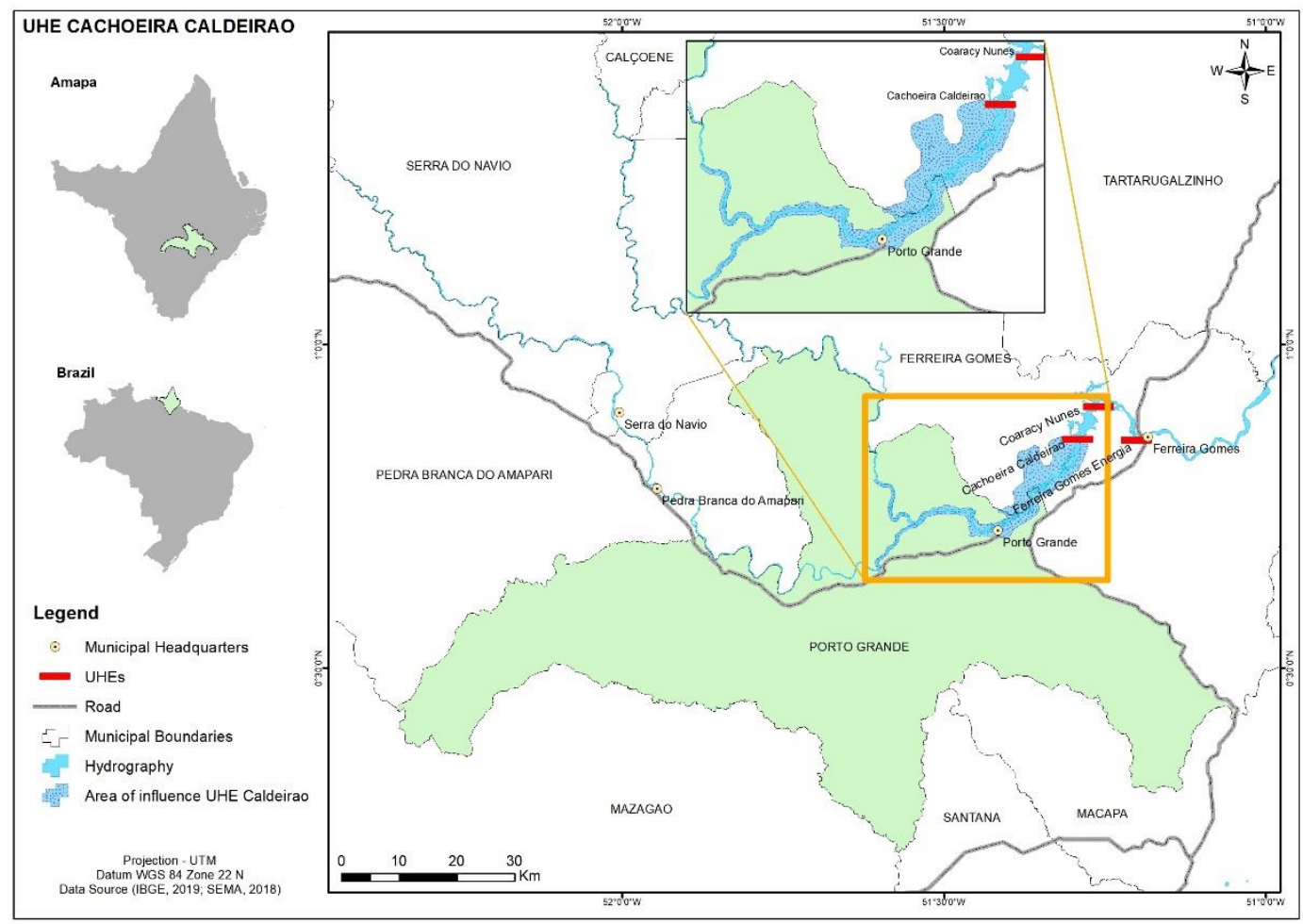

Figure 1. Cachoeira Caldeirão Hydropower Plant (CCHPP) location - Amapá State. Source: Amapá (2003, org. Authors, 2020).

Porto Grande City's urban zone was the site for the study, most precisely the residential area on the Araguari River's banks, since it was the most affected by the CCHPP installation. 


\subsection{Data collection and analysis procedures}

The survey was conducted in 2015, based on questionnaires assigned to 53 families affected by Cachoeira Caldeirão HPP installation. The questionnaires held open- and closedended questions, as follows:

a) What was your family income before and during the hydropower plant's installation? The currency rate (converted into dollars) was R\$3.12, by June 2015 .

b) Which were the wildlife species consumed by you and your family, and how often were they consumed per month, before and during the hydropower plant's installation?

c) Which were the fish species consumed by you and your family, and how often were they consumed per month, before and during the hydropower plant's installation?

The questions referred to food consumption prior to the hydropower plant's installation (August 2013) and during its effective construction (October 2013 to June 2015).

Respondents reported the vernacular names of fish and wildlife species, so they could be gathered and used for data analysis. The families or genera that the fish species mentioned by respondents belonged to were assessed for taxonomic identification, based on the following studies: Ethnoecology of fishermen in the Amapá National Forest (FLONA), by Brandão and Silva (2008); Observation of the lifestyle of FLONA residents, by Costa (2013); Fishery classification in Coaracy Nunes (Amapá State) HPP Reservoir, by Sá-Oliveira et al. (2013).

These surveys were carried out near the study site, since they addressed local families affected by Cachoeira Caldeirão HPP. The International Union for Conservation of Nature's (IUCN, 2018) Red list of Threatened Species was used as reference to identify and audit the scientific names of fish and wildlife species.

Data surveys were carried out from April to June 2015. Residents were contacted prior to the survey in order to assess the number of households affected by the hydropower plant's construction. The total of 224 households was identified. Sampling at $90 \%$ confidence level and 10\% sampling error indicated 53 affected families, as shown in the Equation 1 below.

$n=\frac{\frac{z X p(1-p)}{e^{2}}}{1+\frac{\left(z^{2} X p(1-p)\right.}{e^{2} N}}$

Where in:

$\mathrm{n}=$ sample; $\mathrm{e}=$ margin of error; $\mathrm{z}=\mathrm{z}$ score $; \mathrm{N}=$ sample size .

Respondents were randomized through the snowball sampling method for questionnaire application, since the affected families were not residing in the affected areas. "Catalyst" participants were identified, so that they could successively indicate new participants.

Interviews were conducted in the respondents' respective households and interviewees were preferably the heads of the family. Family members who had information on the assessed subject were interviewed in their absence.

Data collected and recorded in the field survey were systematically arranged in Microsoft Excel 2010 and analyzed in BioEstat 5.3. software (Ayres et al., 2005).

The number of consumed fish and wild meat species, as well as consumption periodicity (before and during the hydropower plant construction) were assessed through Wilcoxon test for paired samples, since it measures and identifies differences between ordinal and numerical variables observed in a given timeframe, after an event. Correlations between variables were assessed through Pearson's correlation test.

Rev. Ambient. Água vol. 16 n. 5, e2700 - Taubaté 2021 


\section{RESULTS AND DISCUSSION}

\subsection{Family income data}

Although an expropriation program was conducted in directly affected areas, 20\% (11) of the families were not expropriated, whereas $80 \%$ (42) of them were expropriated and received compensation for their properties.

Family income changed throughout the assessed periods: Although mean monthly family income was $\mathrm{R} \$ 1.824,79$ (586.56 USD) before the hydropower plant's construction, it decreased to $\mathrm{R} \$ 1.087,54$ (349.57 USD) during its construction - mean decrease by $40.40 \%$ (Figure 2). The Wilcoxon test for paired samples detected a significant difference ( $p$ value $=$ 0.002 ) among family incomes before and during the hydropower plant's construction.

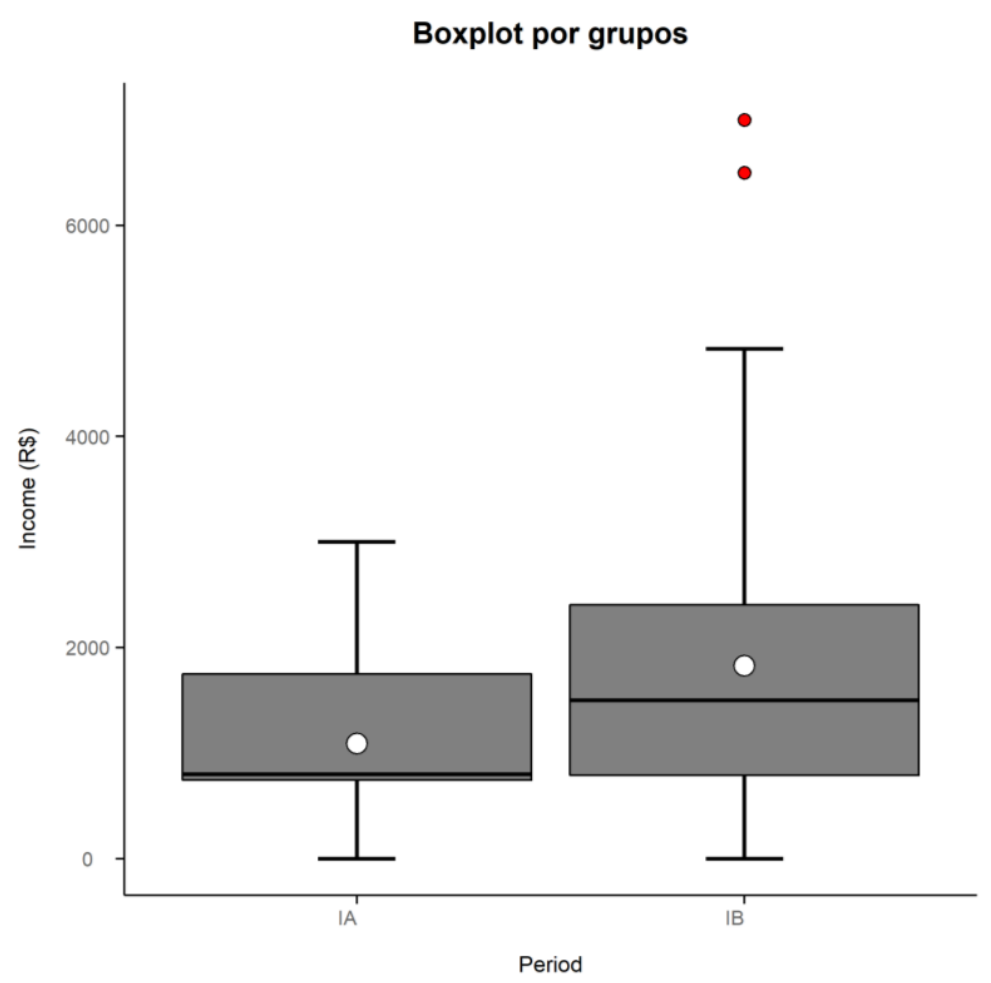

Figure 2. Monthly family income before and during the construction of Cachoeira Caldeirão Hydropower Plant in Amapá State.

Source: Authors (2020).

Cities surrounding hydropower plants, or affected by them, experience changes in their socioeconomic dynamics over time (Tetteh et al., 2004). These socioeconomic changes can have different effects on each social stratum. In essence, dam projects strongly affect the economy of families living near them (Filizola et al., 2002; Holanda et al., 2011).

Other studies have shown similar impacts on the income of families affected by dams. The hydrological cycle of the São Francisco River was altered due to Xingó HPP construction, which compromised traditional fishing and agriculture activities (Holanda et al., 2005). Fishermen from Amapá State experienced negative change in their income due to Araguari River's damming during Ferreira Gomes Hydropower Plant's installation (Santos et al., 2017). Family income of São Paulo State's population affected by Tijuco Alto Dam was substantially altered because of the forced displacement from fertile areas (Jeronymo et al., 2012).

Changes in economy and health experienced by communities living near dams are some of the impacts of these projects; those living farther away from them do not experience such a reality (Tetteh et al., 2004). Accordingly, interviewed families showed substantial income 
deficits, and it was indicative of a negative relationship among dams' projects, local population's activities and income sources.

Although changes in family income have been evidenced by other surveys, it is worth noting that socioeconomic impacts depend on the following factors: dams' projects region and the interaction of different social groups with it; social production conditions; dams' projects conduction. Several case studies on the socioeconomic effects of hydropower plant installation have allowed some generalizations about the constancy and intensity of its effects on the affected population (Reis et al., 2003).

\subsection{Animal protein consumption}

Family fish consumption decreased during the assessed period: $96.2 \%$ (51) of surveyed families consumed fish before the hydropower plant's construction, but this rate dropped to $73.6 \%$ (39) during its construction. The most consumed fish species were: Hoplias sp. (trairão), Tometes sp. (curupeté) and Myleus sp. (pacu-branco) (Table 1).

Table 1. Number of fish species consumed by families before and during Cachoeira Caldeirão Hydropower Plant's construction.

\begin{tabular}{|c|c|c|c|c|}
\hline Vernacular Name & Scientific Name & N. Before & N. During & Studies \\
\hline Trairão & $\begin{array}{c}\text { Hoplias } \\
\text { macrophthalmus }\end{array}$ & 49 & 36 & $\begin{array}{c}\text { Soares et al. (2012); Sá-Oliveira } \\
\text { et al. (2013); Morales (2018); } \\
\text { Oliveira } \text { et al. (2018); Costa } \text { et } \\
\text { al. (2020). }\end{array}$ \\
\hline Curupeté & Tometes SP & 42 & 26 & $\begin{array}{l}\text { Soares et al. (2012); Sá-Oliveira } \\
\text { et al. (2013); Morales (2018). }\end{array}$ \\
\hline Pacú-branco & Myleus micans & 41 & 24 & $\begin{array}{l}\text { IBAMA (2007); Soares et al. } \\
\text { (2012); Sá-Oliveira } \text { et al. } \\
\text { (2013); Morales (2018); } \\
\text { Oliveira } \text { et al. }(2018) ; \text { Costa } \text { et } \\
\text { al. }(2020) .\end{array}$ \\
\hline Tucunaré & Cichla SP & 26 & 16 & $\begin{array}{l}\text { IBAMA (2007); Soares et al. } \\
\text { (2012); Sá-Oliveira et al. } \\
\text { (2013); Morales (2018); } \\
\text { Oliveira et al. }(2018) ; \text { Costa } \text { et } \\
\text { al. }(2020) .\end{array}$ \\
\hline Aracú & Leporinus SP & 22 & 13 & $\begin{array}{l}\text { Soares et al. (2012); Sá-Oliveira } \\
\text { et al. (2013); Morales (2018); } \\
\text { Oliveira et al. (2018); Costa } \text { et } \\
\text { al. (2020). }\end{array}$ \\
\hline Mafurá & $\begin{array}{l}\text { Metynnis } \\
\text { lippincottianus }\end{array}$ & 20 & 10 & $\begin{array}{c}\text { Soares et al. (2012); Sá-Oliveira } \\
\text { et al. (2013); Costa et al. } \\
\text { (2020). }\end{array}$ \\
\hline Mandubé & Ageneiosus SP & 20 & 14 & $\begin{array}{l}\text { IBAMA (2007); Soares et al. } \\
\text { (2012); Sá-Oliveira et al. } \\
\text { (2013); Morales (2018); } \\
\text { Oliveira et al. }(2018) ; \text { Costa } \text { et } \\
\text { al. }(2020) .\end{array}$ \\
\hline Branquinha & Curimatidae (Family) & 12 & 7 & $\begin{array}{l}\text { IBAMA (2007); Soares et al. } \\
\text { (2012); Sá-Oliveira } \text { et al. } \\
\text { (2013); Morales (2018); } \\
\text { Oliveira } \text { et al. }(2018) ; \text { Costa } \text { et } \\
\text { al. }(2020) .\end{array}$ \\
\hline ntinue... & & & & \\
\hline
\end{tabular}

Rev. Ambient. Água vol. 16 n. 5, e2700 - Taubaté 2021 


\begin{tabular}{|c|c|c|c|c|}
\hline Continued... & & & & \\
\hline Acará & $\begin{array}{l}\text { PERCIFORMES } \\
\text { (Family); Cichlidae } \\
\text { (Subfamily) }\end{array}$ & 8 & 4 & $\begin{array}{l}\text { IBAMA (2007); Soares et al. } \\
\text { (2012); Sá-Oliveira et al. } \\
\text { (2013); Morales (2018). }\end{array}$ \\
\hline Piranha & $\begin{array}{l}\text { Characidae (Family); } \\
\text { Serrasalminae } \\
\text { (Subfamily) }\end{array}$ & 8 & 5 & $\begin{array}{l}\text { IBAMA (2007); Soares et al. } \\
\text { (2012); Sá-Oliveira et al. } \\
\text { (2013); Morales (2018); } \\
\text { Oliveira et al. }(2018) ; \text { Costa } \text { et } \\
\text { al. }(2020) .\end{array}$ \\
\hline Jiju & $\begin{array}{c}\text { Hoplerythrinus } \\
\text { unitaeniatus }\end{array}$ & 5 & 3 & $\begin{array}{l}\text { IBAMA (2007); Soares et al. } \\
\text { (2012); Morales (2018). }\end{array}$ \\
\hline Uе́ua & Boulengerella cuvieri & 4 & 3 & $\begin{array}{c}\text { Soares et al. (2012); Sá-Oliveira } \\
\text { et al. (2013); Morales (2018); } \\
\text { Oliveira et al. (2018); Costa et } \\
\text { al. (2020). }\end{array}$ \\
\hline Cumarú & Família Characidae & 3 & 2 & Morales (2018). \\
\hline Tamboatá & Callichthys callichthys & 2 & 1 & $\begin{array}{l}\text { Soares et al. (2012); Morales } \\
\text { (2018). }\end{array}$ \\
\hline Acari & $\begin{array}{c}\text { SILURIFORMES } \\
\text { (Family); Loricariidae } \\
\text { (Subfamily) }\end{array}$ & 1 & 0 & $\begin{array}{l}\text { Soares et al. (2012); Morales } \\
\text { (2018); Costa et al. }(2020) .\end{array}$ \\
\hline Anuja & Not Identified & 1 & 1 & $\begin{array}{l}\text { Soares et al. (2012); Morales } \\
\text { (2018). }\end{array}$ \\
\hline Piramutaba & Brachyplatystoma & 1 & 1 & $\begin{array}{c}\text { Morales (2018); Costa et al. } \\
\text { (2020). }\end{array}$ \\
\hline Flaviano & Characidae (Family) & 1 & 1 & $\begin{array}{c}\text { Soares et al. (2012); Costa et al. } \\
\text { (2020). }\end{array}$ \\
\hline Ituí & $\begin{array}{l}\text { GYMNOTIFORMES } \\
\text { (Family); Gymnotidae } \\
\text { (Subfamily) }\end{array}$ & 1 & 1 & Costa et al. (2020). \\
\hline Jacundá & $\begin{array}{c}\text { PERCIFORMES } \\
\text { (Family); Cichlidae } \\
\text { (Subfamily) }\end{array}$ & 1 & 1 & Soares et al. (2012). \\
\hline Рігариси́ & Not Identified & 1 & 1 & $\begin{array}{l}\text { Soares et al. (2012); Morales } \\
\text { (2018); Costa et al. (2020). }\end{array}$ \\
\hline Sarda & $\begin{array}{l}\text { CLUPEIFORMES } \\
\text { (Family); } \\
\text { Pristigasteridae } \\
\text { (Subfamily) }\end{array}$ & 1 & 1 & $\begin{array}{l}\text { Soares et al. (2012); Sá-Oliveira } \\
\text { et al. (2013); Morales (2018); } \\
\text { Costa } \text { et al. (2020). }\end{array}$ \\
\hline
\end{tabular}

Accordingly, family wild-meat consumption has sharply decreased: $96.2 \%$ (51) of surveyed families consumed this protein before the hydropower plant's consumption, but this rate dropped to $35.8 \%$ (19) during its construction. The most consumed wildlife species were Cuniculus paca, Priodontes maximus and Mazama americana (Table 2).

The aforementioned fish species are compatible with those found in the Araguari River and with the ones consumed by riverside communities in the Araguari River Basin (Brandão and Silva, 2008; Sá-Oliveira et al., 2013; Oliveira et al., 2018). This finding proves that fishing is an essential part of the diet of the interviewed families. The consumed species in both assessed periods showed significant difference $(p$ value $=0.007)$ in the Wilcoxon test for paired samples.

Results of species diversity and abundance reduction around dam reservoirs corroborate those in similar studies (Nascimento et al., 2011; Sá-Oliveira et al., 2013; Santana et al., 2014; Oliveira et al., 2018). Yet, the association between qualitative and quantitative decrease in 
fishery resources facing environmental changes, and uncontrolled fishing, is common around hydropower reservoirs (Agostinho et al., 1999; Garavello et al., 2010).

Table 2. Number of wildlife species consumed by families before and during Cachoeira Caldeirão Hydropower Plant's construction.

\begin{tabular}{cccc}
\hline Vernacular Name & Scientific Name & N. Before & N. During \\
\hline Paca & Cuniculus paca & 44 & 19 \\
Giant armadillo & Priodontes maximus & 34 & 15 \\
Deer & Mazama americana & 24 & 12 \\
Collared peccary & Tayassu tajacu & 18 & 6 \\
Tapir & Tapirus terrestris & 12 & 3 \\
Cotia & Dasyprocta aguti & 10 & 1 \\
Alligator & Caiman sp. & 6 & 3 \\
Queixada & Tayassu pecari & 9 & 0 \\
Capybara & Hydrochoerus hydrochoeris & 2 & 1 \\
Red-footed tortoise & Platemys platycephala & 1 & 1 \\
Guariba & Alouatta caraya & 1 & 0 \\
Tracajá & Podocnemis unifilis & 1 & 0 \\
\hline
\end{tabular}

Source: Authors (2020).

We Biological surveys of the ichtofauna, carried out before the construction of the Cachoeira Caldeirão HPP (IBAMA, 2007; Soares et al., 2012; Sá-Oliveira et al., 2013), showed the occurrence of fish species similar to those mentioned by the interviewees, and studies carried out after its construction (Morales, 2018; Oliveira et al., 2018; Costa et al., 2020) also found the presence of the mentioned species. Thus, it is possible to state that the diversity of fish species was not negatively impacted; however, the abundance may have been influenced by the construction of the Cachoeira Caldeirão HPP, as reported by the interviewees and statistically confirmed with the species consumption frequency data.

The Wilcoxon test for paired samples reported statistically significant difference ( $p$ value $=0.0037$ ) in wild meat consumption between both periods (before and during the hydropower plant's construction). This outcome is indicative of the hydropower plants' impacts on the availability of animal species. Such impacts could be attributed to deforestation at the reservoir's surrounding areas, since it affects the local fauna.

Although wild meat consumption is common in the assessed region, none of the consumed species is on the IUCN Red List of Threatened Species (2018). All listed animals are widely spread and can be easily found throughout the Amazon Rainforest and Amapá State's territories.

The interviewed families described hunting and wild animals' sales as common daily activities for local populations - a fact evidenced in similar studies -, although these practices are illegal in Brazil (Dias Junior et al., 2014; Figueiredo and Barros, 2016).

The diet of Amazonian families culturally consists of fish and wild meat. Hunting is most common in the rainy season, since increased river levels hinder access to fish due to their dispersion in flooded areas. Thus, game meat is one of their main food alternatives and plays a vital role in their subsistence (Murrieta and Dufour, 2004; Murrieta et al., 2004; Adams et al., 2005; Silva, 2007; Figueiredo and Barros, 2016).

It is worth noting that hunting and wild meat consumption are related to food choice and consumption. These activities are influenced by ecological, economic and cultural features that shape the sociocultural context of populations that consume this protein type. However, few studies specify the different aspects of wild fauna management, mainly that in the Amazon Rainforest (Richards, 1939; Firth, 1961; De Garine, 1994; Descola, 1998; Viveiros De Castro, 
2002; Ziober and Zanirato, 2014; Figueiredo and Barros, 2016).

\subsection{Animal consumption periodicity}

Fish consumption did not significantly change between months. Although there was drastic decrease in fish consumption from $30(-84.62 \%)$ to 12 times a month $(-69.23 \%)$, the Wilcoxon test for paired samples did not show significant difference ( $p$ value $=0.5136$ ) between the periods before and during the hydropower plant's construction. Such a result indicates that family consumption may be associated with fish purchase rather than with subsistence fishing in the area directly affected by the hydropower plant (Table 3 ).

Table 3. Monthly animal protein consumption by families before and during Cachoeira Caldeirão Hydropower Plant's construction $(\mathrm{F}=\mathrm{Fish}, \mathrm{WM}=$ Wild Meat $)$.

\begin{tabular}{cccc}
\hline Consumption & Protein Source & Before & During \\
\hline 1 time / 2 months & $\mathrm{F}$ & 0 & 3 \\
1 time / month & $\mathrm{F}$ & 3 & 13 \\
2 times / month & $\mathrm{F}$ & 1 & 4 \\
3 times / month & $\mathrm{F}$ & 1 & 1 \\
4 times / month & $\mathrm{F}$ & 7 & 8 \\
8 times / month & $\mathrm{F}$ & 7 & 3 \\
12 times / month & $\mathrm{F}$ & 13 & 4 \\
16 times / month & $\mathrm{F}$ & 5 & 1 \\
20 times / month & $\mathrm{F}$ & 1 & 0 \\
30 times / month & $\mathrm{F}$ & 13 & 2 \\
1 time /6 months & $\mathrm{WM}$ & 7 & 5 \\
1 time /5 months & $\mathrm{WM}$ & 1 & 0 \\
1 time /4 months & WM & 0 & 2 \\
1 time /3 months & WM & 8 & 4 \\
1 time /2 months & WM & 6 & 1 \\
1 time / month & WM & 18 & 5 \\
2 times / month & WM & 3 & 2 \\
4 times / month & WM & 6 & 0 \\
8 times / month & WM & 2 & 0 \\
\hline
\end{tabular}

Source: Authors (2020).

The results suggest that the decreased fish consumption may be related to changes in the eating habits of families that may have partially replaced it with other industrialized and/or ultra-processed foods, such as frozen chicken, canned food, sausages and bologna - which are very common foods in geographically isolated Amazonian riverside areas lacking access to electricity. However, the hydropower plant prevented access to some fishing areas, mainly the surrounding ones. According to respondents, fish became scarce in traditional fishing areas due to increased flow of ships and progressive riverside deforestation.

River seasonality is yet another variable (not herein assessed) that can influence fish consumption. Fish availability can be high or low depending on the water level in both wet and dry periods (Pezzuti and Chaves, 2009).

It should be noticed that fish is one of the main cultural protein sources of the Brazilian people. Mean consumption in urban areas is $3.3 \mathrm{~kg} / \mathrm{year}$, whereas it ranges from 4 to $7.6 \mathrm{~kg} / \mathrm{year}$ in rural areas and Amazonian towns (IBGE, 2010). Drastic and sudden decrease in protein consumption can aggravate local populations' vulnerability, mainly in low-income families that depend on fishing for socioeconomic and food subsistence. 
With respect to wild meat consumption periodically, there was a drastic decrease in the regular consumption: 1, 4 and 8 times per month. The Wilcoxon test for paired samples showed significant difference ( $p$ value $=0.00322$ ) in consumption between periods before and during the hydropower plant's construction (Table 3 ).

Hunting by other communities near the study site must also be taken into consideration when it comes to assessing decreased wild meat consumption, since this activity may have influenced the abundance of consumed species in the assessed period. However, data gathered so far is insufficient to test this hypothesis.

Therefore, animal-consumption changes depend on the environmental context of a given population, since access to alternative protein sources depends on resource availability. Thus, ecological and geographical conditions are key in determining protein source (Torres et al., 2018). In addition to these variables, forest coverage and distance from downtown can influence wildlife distribution (Foerster et al., 2012; Mgawe et al., 2012).

Hunting and wild meat consumption are basic conditions to ensure food provision and family income supplementation (Cymerys et al., 1995). Thus, identifying the eating habits of a given population is key to understanding the relationship between man and biological changes in the environment (Dufour and Teufel, 1995).

The correlation matrix showed significant difference and negative correlation for "family income" association with variables "wild meat consumption before the hydropower plant's installation" ( $p$ value $=0.045$ and $\mathrm{r}=-0.75)$ and "fish consumption during the hydropower plant's installation" ( $p$ value $=0.029$ and $r=-0.83)$ (Figure 3) .

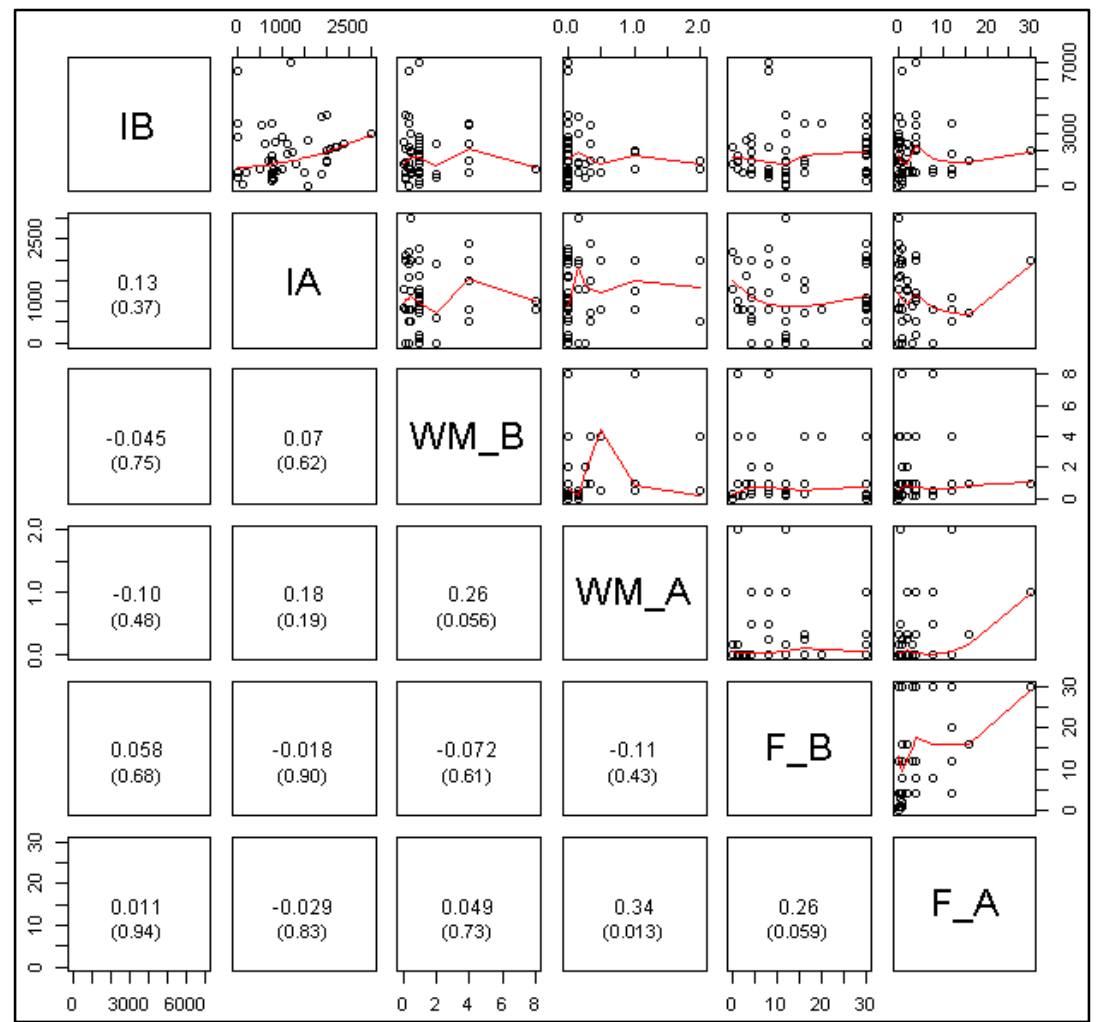

Figure 3. Correlation matrix between variables "family income" and "fish and wild meat consumption before and during Cachoeira Caldeirão Hydropower Plant's construction" (IB = Income Before, IA = Income After, WM_B = Wild Meat before, WM_A = Wild Meat after, F_B = Fish before, F_A = Fish after).

Source: Authors (2020). 
Results can indicate that families have prioritized other protein sources - such as fish over wild meat in the period before the hydropower plant's installation, since their income was higher in this period than during the installation process. On the other hand, families have seemingly prioritized the consumption of industrialized and/or ultra-processed food throughout the installation process, as the wild meat supply decreased. It is noteworthy that most fish and wild meat can be purchased in local markets, a very common practice in Amapá's cities, rather than obtained through hunting and subsistence fishing.

\section{CONCLUSIONS}

The impacts of the hydropower plant on families' fish and wild meat consumption is attributed to changes in the local environment, which affected species' distribution and abundance. These facts were identified in studies on environmental impacts caused by the hydropower plant and confirmed by interviewed families. Moreover, these impacts have seemingly affected local businesses and the consumption of some species by the local population.

Therefore, family eating habits have significantly changed. In addition to family income, the frequency of some fish and wild meat consumption and monthly wild meat consumption by families were also affected. Correlation significance between family income and protein consumption before and during the hydropower plant's construction indicates that families have changed their eating habits due the environmental transformations caused by the hydropower plant's construction in their territories, which imposed diet adaptation on them.

Although the hydropower plant has affected the diversity and abundance of local aquatic and terrestrial fauna, fish and wild meat consumption may have been partially compensated by products sold in neighboring cities. Therefore, the assessed variables could be completed by assessments of the intensity and extent of socio-environmental impacts on the local population.

\section{ACKNOWLEDGEMENTS}

The authors are grateful to the Postgraduate Program in Tropical Biodiversity of the Federal University of Amapá, PROPESPg/UNIFAP, Secretary of State for the Environment/SEMA and all the people who voluntarily participated in the survey. The authors would also like to thank the editor (Dr. Nelson W. Dias) and the anonymous reviewers for all of their comments and insights on the previous versions of the manuscript.

\section{REFERENCES}

ACSELRAD, H. As Práticas Espaciais e o Campo dos Conflitos Ambientais. In: ACSELRAD, H. Conflitos Ambientais no Brasil. Rio de Janeiro: Relume-Dumará, 2004.

ADAMS, C.; MURRIETA, R. S. S.; SANCHES, R. A. Agricultura e Alimentação em Populações Ribeirinhas das Várzeas do Amazonas: Novas Perspectivas. Ambiente \& Sociedade, $\quad$ v. $8, \quad$ n. $1, \quad$ p. $1-22, \quad 2005 . \quad$ https://dx.doi.org/10.1590/S1414753X2005000100005

AGOSTINHO, A. A.; GOMES, L. C.; SUZUKI, H. I.; JÚLIO JÚNIOR, H. F. Riscos da implantação de cultivos de espécies exóticas em tanques-redes em reservatórios do Rio Iguaçu. Cadernos da Biodiversidade, v. 2, n. 2, p. 1-9, 1999.

AMAPÁ. Secretaria de Estado do Meio Ambiente. Base Cartográfica. Macapá, 2003. 
ARAUJO, M A T.; BELO, P. S. Grandes Projetos Minerários e Comunidades Tradicionais na Amazônia: Impactos e Perspectivas. Revista de Políticas, v. 13, n. 2, p. 265-277, 2009.

AYRES, M. et al. Software BioEstat 5.0. Belém: Instituto de Desenvolvimento Sustentável Mamirauá/IDSM/MCT/CNPq, 2005.

Begossi, A. A. Ecologia de Pescadores da Mata Atlântica e da Amazônia. São Paulo: Hucitec, 2004. 332p.

BEGOSSI, A. A. Ecologia Humana: Um Enfoque das Relações Homem Ambiente. Interciência, v. 18, n. 1, p. 121-132, 1993.

BERMANN, C. Impasses e controvérsias da hidrelétrica. Estudos Avançados, v. 21, n. 59, 2007. https://doi.org/10.1590/S0103-40142007000100011

BRANDÃO, F. C.; SILVA, L. M. A. Conhecimento Ecológico Tradicional dos Pescadores da Floresta Nacional do Amapá. UAKARI, v. 4, n. 2, p. 55-66, 2008. https://doi.org/10.31420/uakari.v4i2.43

CAVAlCANTE, M. M. A.; SANTOS, L. C. Hidrelétricas no Rio Madeira RO: tensões sobre o uso do território e dos recursos naturais na Amazônia. Confins, n. 15, 2012. https://doi.org/10.4000/confins.7758

COSTA, R. A. A Identificação e o Conhecimento Etnobotânico dos Moradores da Floresta Nacional do Amapá. 2013. Dissertação (Mestrado em Biodiversidade Tropical) UNIFAP, Macapá, 2013.

COSTA. O. C.; GAMA. C. S.; HACON. S. S.; BASTA. P. C.; FERREIRA. R.; YOKOTA. D. Exposição ao mercúrio pelo consumo de peixes: o potencial impacto à saúde das populações locais e economia pesqueira do Amapá. Nota Técnica. WWF/Iepa/Iepé/Fiocruz, 2020. Available at: https://wwfbr.awsassets.panda.org/downloads/nota_tecnica_contaminacao_peixes_ama pa_1_1.pdf. Acess: Aug. 2021.

CUNHA, A. C.; BRITO, D. C.; CUNHA, H. F. A.; SCHULZ, H. E. Dam Effect on Stream Reaeration Evaluated with the Qual2kw Model: Case Study of the Araguari River, Amazon Region, Amapá State/Brazil. In: BILIBIO, C.; HENSEL, J. F. S.; SELBACH, J. (Orgs.). Sustainable Water Management in the Tropics and Subtropics. 1. ed. Jaguarão: UniKassel; Fundação Univ. Fed. do Pampa, 2011. p. 150-174.

CYMERYS, M.; SHANLEY, P.; LUZ, L. Caça, um Incentivo para a Conservação na Amazônia? Ciência Hoje, v. 22, 1995.

DE GARINE, I. The diet and nutrition of human populations. In: INGOLD, T. (Ed.). Companion Encyclopedia of Anthropology. London: Routledge, 1994. p. 226-264.

DESCOLA, P. Estrutura ou sentimento: a relação com o animal na Amazônia. Mana, v. 4, n. 1, p. 23-45, 1998. https://doi.org/10.1590/S0104-93131998000100002

DIAS JÚNIOR, M. B. F.; CUNHA, H. F. A.; DIAS, T. C. A. Caracterização das apreensões de fauna silvestre no estado do Amapá, Amazônia oriental, Brasil. Biota Amazônia, v. 4, n. 1, p. 65-73, 2014. https://doi.org/10.18561/2179-5746/biotaamazonia.v4n1p65-73

DUFOUR, D. L.; TEUFEL, N. I. Minimum data sets of he escription o diet and measure-ment of food intake and nutritional status. In: MORAN, E. F. (Ed). The Comparative Analysis Of Human Societies. Boulder: Lynne Rienner, 1995. p. 97-128. 
FEARNSIDE, P. M. Impacts of Brazil's Madeira River Dams: Unlearned Lessons for Hydroelectric Development in Amazonia. Environmental Science \& Policy, v. 38, p. 164-172, 2013. https://doi.org/10.1016/j.envsci.2013.11.004

FIGUEIREDO, R. A. A.; BARROS, F. B. Caçar, preparar e comer o 'bicho do mato': práticas alimentares entre os quilombolas na Reserva Extrativista Ipaú-Anilzinho (Pará). Boletim do Museu Paraense Emílio Goeldi, v. 11, n. 3, p. 691-713, 2016. https://doi.org/10.1590/1981.81222016000300009

FILIZOLA, N. J. L.; GUYOT, M.; MOLINIER, V.; GUIMARÃES, E., OLIVEIRA; M.A, FREITAS. Caracterização hidrológica da Bacia Amazônica. In: RIVAS, A.; FREITAS, C. E. C. Amazônia uma Perspectiva Interdisciplinar. Manaus: EDU, 2002. p. 33-53.

FIRTH, R. We, the Tikopia: a sociological study of Kinship in Primitive Polynesia. $2^{\text {nd }}$ ed. London: Allen \& Unwin, 1961.

FOERSTER, S.; WILKIE, D. S.; MORELLI, G. A.; DEMMER, J.; STARKEY, M.; TELFER, P.; STEIL, M.; LEWBEL, A. Correlates of bushmeat hunting among remote rural households in Gabon, Central Africa. Conservation Biology, v. 26, p. 335-344, 2012. https://doi.org/10.1111/j.1523-1739.2011.01802.x

GARAVELlO, J. C. A.; GARAVELlO, J. P. B.; OLIVEIRA, A. K. C. Ichthyofauna, fish supply and fishermen activities on the mid-Tocantins River, Maranhão State, Brazil. Brazilian Journal of Biology, v. 70, n. 3, p. 575-585, 2010. https://doi.org/10.1590/S1519-69842010000300014

GIUSTI, M. C. H. Conflictos Ambientales en la Gestión del Santuario Histórico de Machupicchu: El Caso de la Instalación y Manejo de la Central Hidroeléctrica Machupicchu. 2005. Tese (Master En Ciencias Sociales) - Escuela Andina de PostGrado Maestria En Gestion Ambiental y Desarrollo, Cusco, 2005.

GUIMARÃES, R. P. La ética de la sustentabilidad y la formulación de políticas de desarrollo. In: ALIMONDA, H. (org.). Ecología política: Naturaleza, sociedad y utopía. Buenos Aires: Clacso, 2003. 350p.

HOLANDA, F. S. R.; SANTOS, L. C. G.; ARAUJO FILHO, R. N.; PEDROTTI, A.; GOMES, L. J; SANTOS, T. O; CONCEIÇÃ̃O, F. G. Percepção dos ribeirinhos sobre a erosão marginal e a retirada da mata ciliar do rio São Francisco no seu baixo curso. RA'EGA, v. 22, p. 219-237, 2011. https://doi.org/10.5380/raega.v22i0.21773

HOLANDA, F. S. R.; SANTOS, L. G. C.; SANTOS, C. M.; CASADO, A. P. B.; PEDROTTI, A.; RIBEIRO, G. T. Riparian Vegetation Effected by Bank Erosion in the Lower São Francisco River, Northeastern Brazil. Revista Árvore, v. 29, p. 327-336, 2005. https://doi.org/10.1590/S0100-67622005000200016

IBAMA. Estatística da Pesca Brasil, Grandes Regiões da Federação. Brasília, 2007.

IBGE. Cidades. 2018. Available at: http:// www.ibge.gov.br/cidadesat/topwindow.htm?1 Access: Aug. 2021.

IBGE. Pesquisa de Orçamentos Familiares, Aquisição alimentar domiciliar per capita. Rio de Janeiro, 2010.

IUCN. The IUCN Red List of Threatened Species. Version (2018). 2018. Available at: http://www.iucnredlist.org Access: Aug. 2021. 
JERONYMO, A. C. J.; BERMANN, C.; GUY-GUERRA, S. M. Displacements, Itineraries and Destinations of Populations Affected by Dams: HP Tijuco Alto, SP-PR. Desenvolvimento e Meio Ambiente, v. 25, p. 133-152, 2012. https://doi.org/10.5380/dma.v25i0.25273

LEKWOT, V. E. et al. Impact of Lamingo Dam on The Socio-Economic Activities of The People In Jos Area of Plateau State, Nigeria. Case Studies Journal, v. 3, n. 12, p. 32-39, 2016.

MARQUES, G. S.; GIONGO, C. R.; CRUZ, F. K. T.; MENDES, J. M. R. Deslocamento forçado e saúde mental: o caso da hidrelétrica de Itá. Revista de Estudios Sociales, v. 66, p. 30-41, 2018. https://doi.org/10.7440/res66.2018.04

MARTINEZ-ALIER, J. Justiça Ambiental. In: CAVALCANTI, C. Meio Ambiente, Desenvolvimento Sustentável e Políticas Públicas. São Paulo: Cortez, 1999. p. 215231.

MGAWE, P.; MULDER, M. B.; CARO, T.; MARTIN, A.; KIFFNER, C. Factors affecting bushmeat consumption in the Katavi-Rukwa ecosystem of Tanzania. Tropical $\begin{array}{llllll}\text { Conservation } & \text { Science, } & \text { v. } & 5, & \text { p. } & 446-462,\end{array}$ https://doi.org/10.1177/194008291200500404

MORALES, U. S. Características da pesca e produção pesqueira do médio Araguari, Ferreira Gomes, Amapá, Brasil. 2018. 97f. Dissertação (Mestrado em Desenvolvimento Regional) - UNIFAP, Macapá, 2018.

MORENO, E. S.; OLIVEIRA, J. C.; SHIMABUKUR, P. H. F.; CARVALHO, L. Environmental licensing of large-scale enterprises: what are the limits for evaluating direct and indirect impacts on health? A case study in the Wajãpi Indigenous Land, Amapá. Boletin do Museu Paraense Emílio Goeldi. Ciências Humanas, v. 13, n. 3, 2018. https://doi.org/10.1590/1981.81222018000300003

MORETTO, E. M.; GOMES, C. S.; ROQUETTI, D. R.; JORDÃO, C. O. Histórico, tendências e perspectivas no planejamento espacial de usinas hidrelétricas brasileiras: a antiga e atual fronteira amazônica. Ambiente \& Sociedade, v. 15, n. 3, p. 141-164, 2012. https://doi.org/10.1590/S1414-753X2012000300009

MURRIETA, R. S. S.; BATISTONI, M.; PEDROSO JUNIOR, N. Consumo alimentar e ecologia em populações ribeirinhas na Região da Floresta Nacional de Caxiuanã (PA). Boletim Rede Amazônia, v. 3, n. 1, p. 85-94, 2004.

MURRIETA, R. S. S.; DUFOUR, D. L. Fish and Farinha: protein and energy consumption in Amazonian Rural Communities on Ituqui Island, Brazil. Ecology of Food and Nutrition, v. 43, p. 231-55, 2004. https://doi.org/10.1080/03670240490447550

NASCIMENTO, S. F.; MELLO, A. H.; OLIVEIRA, G. F.; PEREIRA, V. D. N.; MENDES, A. S. Queda da Produtividade de Pescado no Rio Tocantins: A Percepção dos Pescadores de Marabá/Pará. Agroecossistemas, v. 3, n. 1, p. 101-105, 2011. https://doi.org/10.18542/ragros.v3i1.1389

OLIVEIRA, I. S.; CUNHA, F. C.; PRESTES, L. P.; SANTOS, E. A.; SANTOS, E. A.; SOARES, M. G.; FLORENTINO, A. C. A Pesca Artesanal no Alto e Médio Rio Araguari, Amapá, Brasil. Holos, v. 08, p. 81-98, 2018. https://doi.org/10.15628/holos.2018.6820 
OLIVEIRA, L. L.; CUNHA, A. C.; JESUS, E. S.; BARRETO, N. J. C. Características Hidroclimáticas da Bacia do Rio Araguari. In: CUNHA, A. C. et al. Tempo, Clima e Recursos Hídricos: Resultados do Projeto REMETAP no Estado do Amapá. Macapá: IEPA, 2010. p. 83-118.

PEZZUTI, J. C. B.; CHAVES, R. Etnografia e manejo de recursos naturais pelos índios Deni, Amazonas, Brasil. Acta Amazônica, v. 39, n. 1, p. 121-138, 2009. https://doi.org/10.1590/S0044-59672009000100013

REIS, M. J.; CATUllo, M. R.; CASTEllS, A. N. G. Patrimônio: reassentamento compulsório e turismo. Um estudo comparativo sobre Federación (Argentina) e Itá (Brasil). Ilha. Revista de Antropologia, v. 5, n. 2, 2003.

RICHARDS, A. I. Land, labour and diet in Northern Rhodesia: An Economic Study of the Bemba Tribe. London: Int. Inst. of African Lang. Cult.; Oxford Univ. Press, 1939. 415p.

RICHTER, B. D. et al. Lost in development's shadow: The downstream human consequences of dams. Water Alternatives, v. 3, n. 2, p. 14-42, 2010.

SANTANA, A. C.; BENTES, E. S.; HOMMA, A. K. O.; OLIVEIRA, F. A., OLIVEIRA, E. C. M. Influência da Barragem de Tucuruí no Desempenho da Pesca Artesanal, Estado do Pará. Revista de Economia e Sociologia Rural, v. 52, n. 02, p. 249-266, 2014. https://doi.org/10.1590/S0103-20032014000200003

SANTOS, E. S.; CUNHA, A. C.; CUNHA, H. F. A. Hydroelectric power plant in the amazon and socioeconomic impacts on fishermen in Ferreira Gomes county - Amapá State. Ambiente \& Sociedade, v. 20, p. 191-208, 2017. https://doi.org/10.1590/18094422asoc0088r2v2042017

SÁ-OLIVEIRA, J. C.; ISAAC, V. J.; ARAÚJO, A. S.; FERREIRA, S. F. Factors structuring the fish community in the area of the Coaracy Nunes hydroelectric reservoir in Amapá, northern Brazil. Tropical Conservation Science, v. 9, n. 1, p. 16-33, 2016. https://doi.org/10.1177/194008291600900103

SÁ-OLIVEIRA, J. C.; VASCONCELOS, H. C. G.; PEREIRA, S. W. M.; ISAAC NAHUM, V. J.; TELES JUNIOR, A. P. Caracterização da pesca no Reservatório e Áreas Adjacentes da UHE Coaracy Nunes, Ferreira Gomes, Amapá - Brasil. Biota Amazônia, v. 3, n. 3, p. 83-96, 2013. https://doi.org/10.18561/2179-5746/biotaamazonia.v3n3p83-96

SIEBEN, A.; CLEPS JUNIOR, J. Política Energética na Amazônia: A UHE Estreito e os Camponeses Tradicionais de Palmatuba/ Babaçulândia (TO). Sociedade \& Natureza, v. 24, n. 2, p. 183-196, 2012. https://doi.org/10.1590/S1982-45132012000200002

SILVA, A. L. Comida de gente: preferências e tabus alimentares entre os ribeirinhos do Médio Rio Negro (Amazonas, Brasil). Revista de Antropologia, v. 50, n. 1, p. 125-179, 2007. https://doi.org/10.1590/S0034-77012007000100004

SILVA, C. N.; LIMA, R. A. P.; SILVA, J. M. P. Uso do território e impactos das construções de hidroelétricas na bacia do rio Araguari (Amapá-Brasil). PRACS: Revista Eletrônica de Humanidades do Curso de Ciências Sociais da UNIFAP, v. 9, n. 2, p. 123-140, 2016. https://doi.org/10.18468/pracs.2016v9n2.p123-140

SOARES, M. G. M.; BATISTA, G.; CUNHA. F. C.; PRESTES. L. Bioecologia e etnoecolocia da ictiofauna na Floreta Nacional do Amapá como subsídio para o manejo do recurso pesqueiro. Relatório de pesquisa. Conservação Internacional Brasil/CI, 2012. 
SOUSA, W. L. Impacto Ambiental de Hidrelétricas: uma análise comparativa de duas abordagens. 2000. Dissertação (Mestrado em Planejamento energético) - Programa de Pós Graduação de Engenharia, UFRJ, Rio de Janeiro, 2000.

TETTEH, I. K.; FREMPONG, E.; AWUAH, E. An analysis of the environmental health impact of the Barekese Dam in Kumasi, Ghana. Journal of Environmental Management, v. 72, n. 3, p. 189-194, 2004. https://doi.org/10.1016/j.jenvman.2004.04.012

TORRES, P. C.; MORSELLO, C.; PARRY, L.; BARLOW, J.; FERREIRA, J.; GARDNER, T.; PARDINI, R. Landscape correlates of bushmeat consumption and hunting in a postfrontier Amazonian region, Environmental Conservation, v. 45, n. 4, p. 315-323, 2018. https://doi.org/10.1017/S0376892917000510

VIVEIROS DE CASTRO, E. A inconstância da alma selvagem e outros ensaios de Antropologia. São Paulo: Cosac \& Naify, 2002. 552p.

ZAGALLO, A. D. A.; ERTZOGUE, M. H. Os sentimentos eles nunca vão indenizar: Tecendo memórias de mulheres ribeirinhas. INTERthesis, v. 15, n. 2, p. 91-108, 2018. https://doi.org/10.5007/1807-1384.2018v15n3p91

ZHOURI, A.; OLIVEIRA, R. Desenvolvimento, conflitos sociais e violência no Brasil Rural: o caso das usinas hidrelétricas. Ambiente \& Sociedade, v. 10, n. 2, p. 119-135, 2007. https://doi.org/10.1590/S1414-753X2007000200008

ZIOBER, B. A.; ZANIRATO, S. H. Ações para a salvaguarda da biodiversidade na construção da Usina Hidrelétrica Itaipu Binacional. Ambiente \& Sociedade, v. 17, n. 1, p. 59-78, 2014. https://doi.org/10.1590/S1414-753X2014000100005 